\title{
WHOOPING CRANE AT GLASLYN, SASKATCHEWAN, 1969
}

by Fred W. Lahrman and Lorne Scott, Saskatchewan Museum of

Natural History

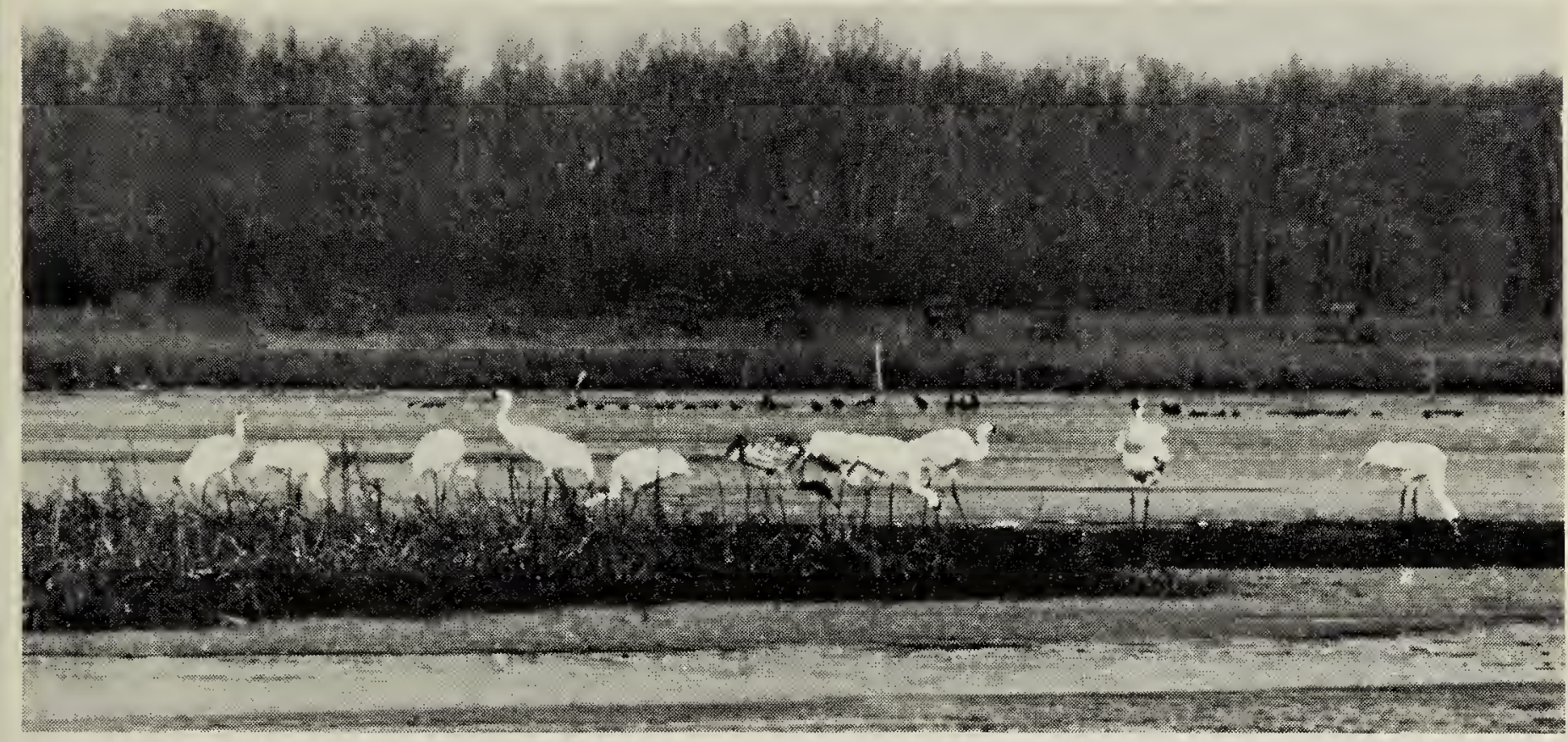

Saskatchewan Museum of Natural History Photo

This unusual photograph of 11 Whooping Cranes was taken on October 15, 1969, near Glaslyn, Saskatchewan. The cranes, first seen in the area on October 11, were reported to the Museum by Grant Fladager, Regional Supervisor, Meadow Lake, and we came up from Regina to field check the report. We arrived in Glaslyn about 9:30 p.m., where we met the Conservation Officer, Glen Vilness, who gave us further information about where the cranes had been seen. Early the following morning we set out to check Midnight Lake, approximately seven miles north of Glaslyn, and the nearby stubble fields. At 9:30 a.m. we found the group of 10 adults and one juvenile in a field of swathed grain. At 10:50 a.m. the cranes left the field and, flying southwest towards the lake, started circling and calling. They quickly gained altitude, and I feared that they were leaving, but they glided back down to land on the lake. Here we had an excellent view of them, and were able to get good photographs from as close as 200 yards, in good light. The Whoopers were grouped fairly close together, standing on the ice and resting and preening. As they walked they often flipped their wings to maintain their balance on the thin, slippery ice.

Towards 2:00 p.m. the cranes began wandering about searching for food in the open patches of water, and the parents were observed feeding the young several times. The family group walked aivay from the rest of the group, and made a short flight to the east shore. The others followed on foot. At $3: 15$ p.m. the family group took to the air again, heading northwest towards the fields, and they were again followed shortly afterwards by the others. Near the west side of the lake they started soaring again, and soon re-united in one group. Then they were seen to alight in the distance and were found to have settled near their morning location. Before returning to Regina, we stayed at the lake until it became dark at 7:00 p.m., hoping for their return, but the cranes did not come back. However, a radiogram from Grant Fladager reported that the cranes were still in the area on October 20. 